日本内科学会学術集会

内科学の展望 $(\text { 第 } 2 \text { 回 })^{*}$

血液疾患を中心として

闹山大学医学部第二内科

会長 平木 潔

REVIEW ON INTERNAL MEDICINE, 1974-HEMATOLOGY-

President of the Scientific Session: Kiyoshi Hrrakr, M.D.

The Second Department of Internal Medicine, Okayama University Medical School

国立名古屋病院長

座長 日比野 進

Chairman: Susumu Hrbino, M.D.

Director of National Nagoya Hospital

（1）再生不良性貧血の臨床

岡山大学医学部第二内科

岩崎 一郎

(1) CLINICAL ASPECTS OF HYPOPLASTIC ANEMIA

I chiro IWASAKI, M.D.

The Second Department of Medicine, Okayama University, Medical School

I. はじめに

再生不良性貧血なる名称は1935年に故小宮教授 により名付けられたが，1888年Ehrlichのaplastische Anämieの報告以来, 血液学では甚だ重要な 疾患である。しかし，その成因は未だに不明で， 治療にも甚だ困惑するのが現状である. 昭和 47 年 度より厚生省の“特定疾患”研究の一つとして， 再生不良性貧血研究班が組織されたのも，かかる 背景があつたからである。

本稿では主に本態性再生不良性筫血について述 ベることとする．

* 本講演は1974年12月15日（日）仙山市古京町 累衛生会館三木記念ホールにて行なわれた。
II. 再生不良性實血の定義 診断基準 ${ }^{1)}$

本症を論ずるに当り，先ず重要なことは診断基 準の確立であるが，再生不良性貧血研究班の「定 義等に関する委員会」による案は（表 1) のとお りである．I，II項により本症を疑い，正項で他 疾患を除外し，IV項により診断をさらに確実にす ることになる。

\section{III. 再生不良性實血患者の実龍}

昭和47年11月から昭和48年夏にかけて行なわれ た再生不良性貧血研究班第一次調查 ${ }^{2}$ によれば， 実患者数 2,545 名（報告分），全国有病者数 3,220 〜 5,054名（推定）である. その年令別分布では 50才以上で急上昇し，男では70 74才で人口 100

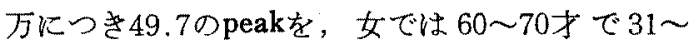


表 1。再生不良性筫皿を竞断するための基淮（案） (高久)

（1）末梢血において沉速球少症をみとめる。

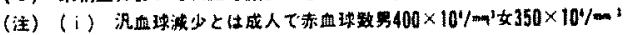

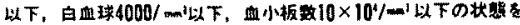
きしている。

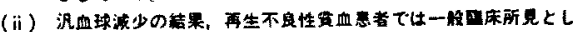

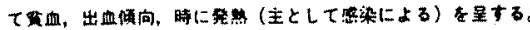

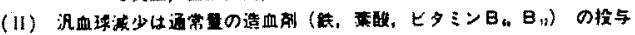
に反心しない。

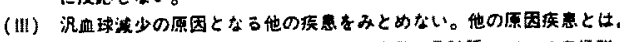

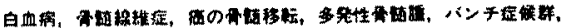

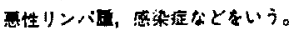

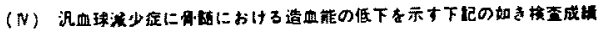

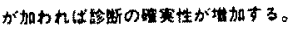

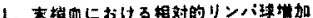

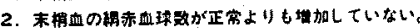

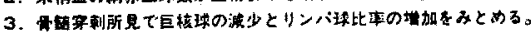

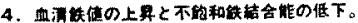

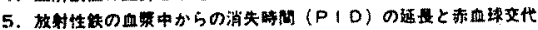
丰(RIT) の低下。

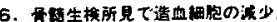

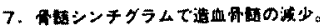

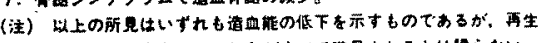

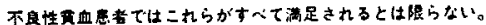

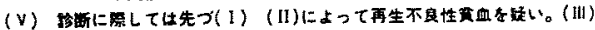

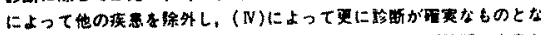

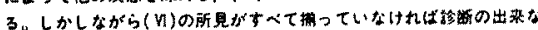

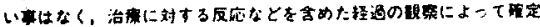
拉断に到通する。

38/100万の小高い丘をつくる．推定発病時年令別 分布も有病者年令別分布と同じ傾向で，老年者の 発病が多い（人口 100 万につき 30 前後）が，この ほかに0〜4才とくに0才での発病が 100万につ き約15と多いのが目立つ.

病型別では，本態性再生不良性貧血が大部分を 占める。

地域別分布では，中国・四国・九州化高率な分 布がみられる。

死亡統計からみると音，本症死亡率は男女とす 諸外国に比べて本邦が高く，とくに50才以上で急 増するのが特徵的である。

\section{IV. 再生不良性貫血の成因}

本症の成因にかんする学説は種々発表されてい るが，現在では幹細胞障害説と，骨髄静脈洞一毛 細管障害説が有力は意見と考えられるので，先ず これらについて簡単に触れ，次にわれわれの現在 行なつている成因へのアプローチについて述べる こととする。

\section{1）幹細胞障害説}

高久ら ${ }^{(3) 63}$ は，再生不良性炃血は， erythropoietic disorderskかんするJandle ${ }^{7} の$ 分類の中の “erythropoiesisの早期の段階での分化の障害”に 相当するといら考えを基にして，再生不良性坌血 では幹細胞が，自己免度あるいは， viral infection のような何らかの障害を受けて，造血障害を来た していると推諭している.

詳細は本展望の 4 席での高久教授の報告を参照 されたい。

\section{2）骨的道静脈洞一毛細血管障害説}

Sinocapillaropathy of the bone marrow

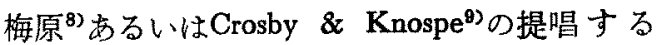
説であるが，梅原は本症は亜急性ないし慢性炎症 による骨䯣の血管機能の失調により，障書の強い 時には造血必需物質が骨髄へ全く入らなくなり， いわゆるimport aplasiaが扣こり, 炎症の程度が 弱く, 漫出性病変が余り強くない時には骨䯣では hyperplasia，末梢血ではpancytopeniaのみられる export aplasiaになると主張している。

これは，われわれの教室で行なつている本症の 病型分類の説明にむ便利で，かなり妥当性がある ように考支るが，血管障害の原因が説明されてい ない，この原因には当然，自己免疫あるいはviral infectionなども推湘される。

\section{3）われわれの研究}

教室では再生不良性貧血と, その胸腺機能との 関係を追究し，本症の解明をこころみようとして いる.

a ）赤芽球瘵症とその免疫学的異常について われわれは図 1 に示すような経過をとつた赤芽 球㾤症の 1 例を経験した ${ }^{10}$.

すなわら，67才の男性で，昭和44年頃より両上 肢に, 重症篎無力症症状が出現し, 昭和 47 年 3 月 に胸部X線像で右肺門部に胸腺腫を指摘され，昭 和48年 2 月頃から貧血が増強し，同年 4 月に教室 へ入院した。

入院後の諸娭査成績より赤芽球涳症と䛦断し， 昭和 48 年 5 月末に胸腺摘出を行なつた。

術後，筋無力症症状は改善したが，骨䯣に括け る赤芽球系細胞の増加は $0.8 \%$ と極めて僅かであ つた.

術後84日目から免度抑制剤イムラン 100mgの併 


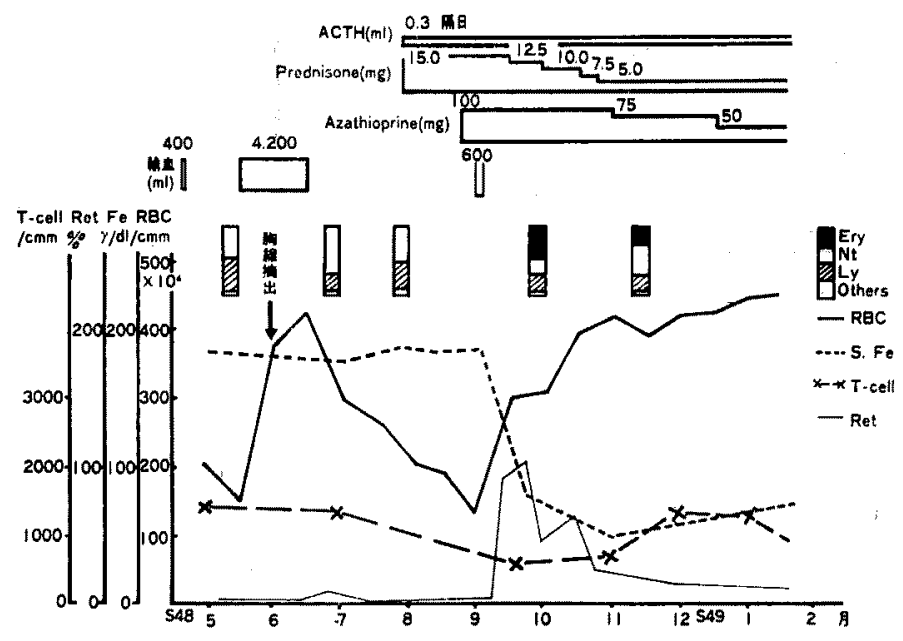

図 1。胸腺摘出後の経通

用を開始したところ，3 週目ごろから赤血球数， 血色素量ともに急速に增加 し始め, 網赤血球89 $\%$ ，骨髄の赤芽球系細胞 $46.2 \%$ ，血清鉄 $86 \gamma / \mathrm{dl}$ と なり，以後順調に貧血の改善が認められ，汪ぼ寛 解の状態にいたつた。

赤芽球痨症の発生に対する胸腺の役割について は，断定的なことはい之ないが，提示した症例の 摘出胸腺中には少量 $(5.5 \%)$ ながらB-cellの存 在が認められて打り，抗核抗体，抗赤芽球抗体， Coombs試験などでも陽性を示しており，免疫学 的異常の存在 ${ }^{1112}$ が推測される。また，免疫抑制 剤使用により貧血が好転したことも，本症の発現 に免疫学的機序の関与したことを示唆するものと 考える。

b ）再生不良性炃血末梢血 リンパ球subpopulation

再生不良性貧血患者の胸腺機能と本症発現の関 係を確かめる目的で，ヒツジ赤血球ロゼット形成 細胞 ${ }^{13)}$ によるT-cellおよびsurface immunoglobulin bearing cell (SIBC) によるB-cellの検索を行なつ た。

成績：健康人では末梢血subpopulation (図 2) はT-cell 60.9\%，B-cell 30.5\%であるのに対し $\tau$, surface markerがヒッジ赤血球とロゼットを

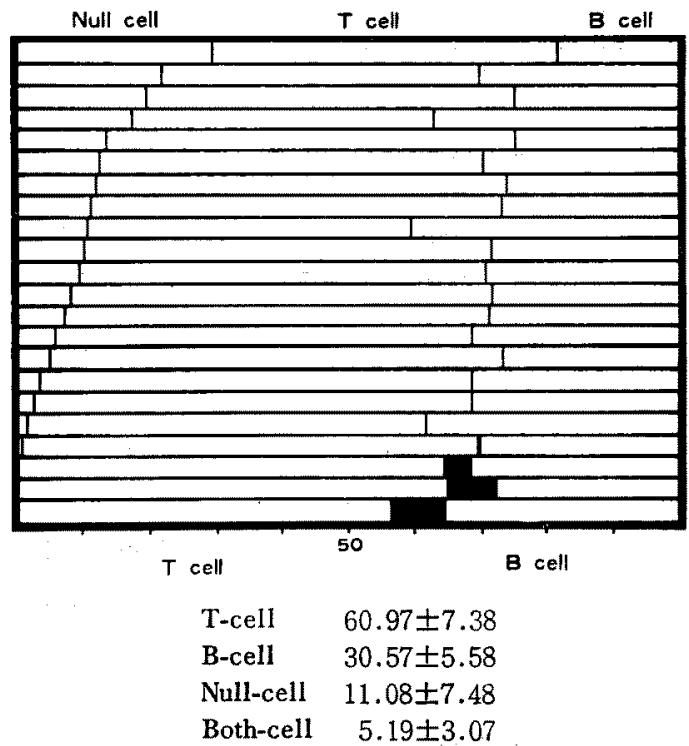

図2，健康人末梢血リンパ球構成（\%)

形成せず， surface immunoglobulinももたない， null cell が約 $11 \%$ 存在し; 禹者のmarkerをるつ both cellか⿱ $5 \%$ 存在する。

これに対して再生不良性䆩血では図 3 の如き成 績を示し，T-cell 65\%，B-cell 19\%, null cell 19 $\%$, both cell $5 \%$, null cellの増加とB-cellの 減少傾向が認められる。 


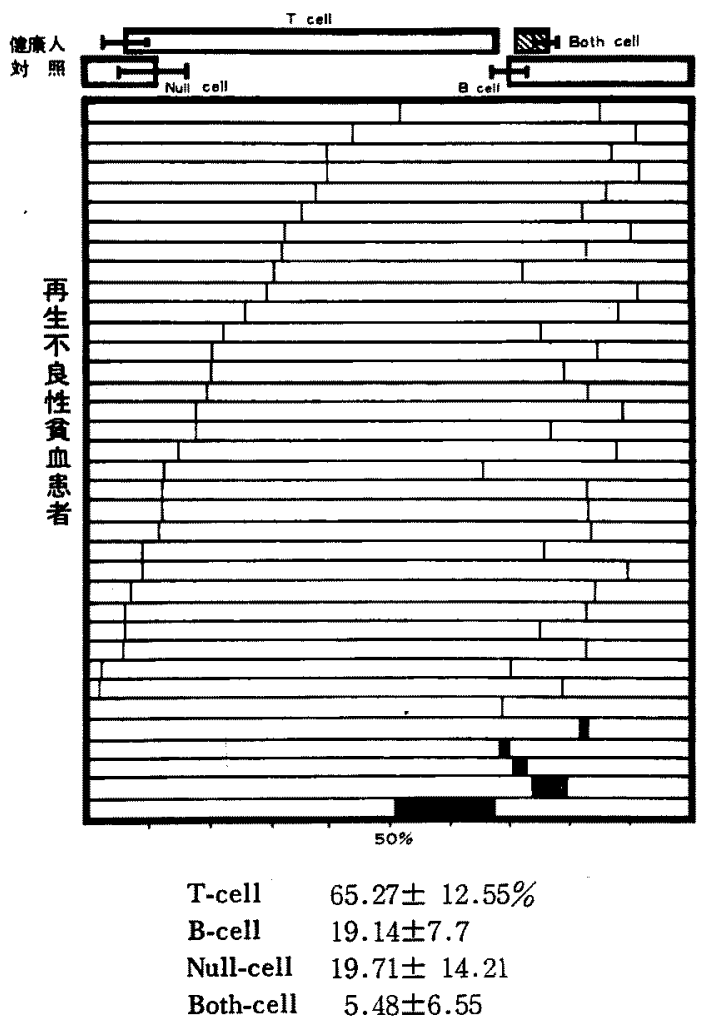

図 3，再生不良性貧血患者末梢血リンパ球粠成（\%)

検索を行なつた全症例をnull cellの多い順に並 べてあるが， null cellのとくに著増している症例 ではT-cellが減少し，B-cellの減少も著しく，い ずれる死亡例および重症例であつた， both cellの 出現するような症例はもしろ宽解例で，T-cellが 多く，明らかにnull cellが減少している。

これらの成績は再生不良性貧血のリンパ球は重 症になると, surface markerの著しい異常を来たす ことを示している。

次比，再生不良性貧血の予後に関係があると考 觉られる諸因子と，T-cell，B-cellの百分率の関係 をみると，Hbおよび栓球数との間に相関が認め られる。すなわち，Hbが減量するに従い，Tcellが減少し，B-cellがやや増加を示し，栓球数 の減少が著しい重症例ではT-cell, B-cell\%が減少 字示す。

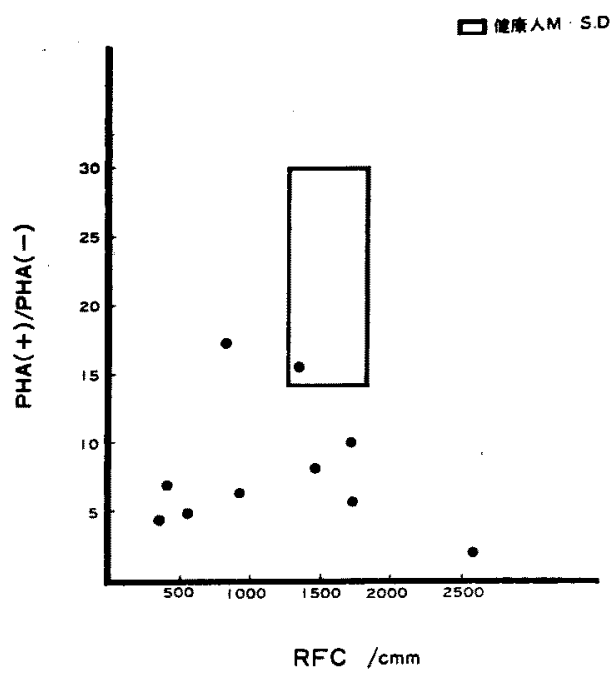

図 4，再生不良性贫血患者末梢血 リンパ ( R F C ) と P H A 反応性の相関

さらに再生不良性貧血の重症度との関係をみる と，重症になるにしたがい，リンハ球数が減少 し, T-cellもB-cellもともに減少する.

ッベルクリン反応とは，その反応が強いものに T-cell高率の傾向がうかがわれる。

c）再生不良性貧血末梢リンバ球の機能

T-cell扣よびB-cellの機能面の検索を，phytohemoaggulutinin (PHA) 柿よび porkweed mitogen (PWM) 飞対する反応性からみると，P HA反 応性は重症になるにつれて減少するが，PWM反 応性には余り変化がみられない。

このP H A反応性をT-cell数との相関でみると （図 4），再生不良性貧血ではT-cell数は多い例か ら少ない例までばらつきはあるが，PHA反応性 は概して低下を示す。すなわら，P HA反応性は 一応T-cell specificと考えられているから，T-cell 機能の低下が再生不良性貧血では認められること になる。

P WM反応性とB-cellとの相関（図 5)をみる と，PWM反応性は比較的保持されて和り， P W M反応性がよりB-cell specificと仮定可れば，再 生不良性貧血ではB-cellよりるT-cellのdeficitが前 面に出ているといえる。 


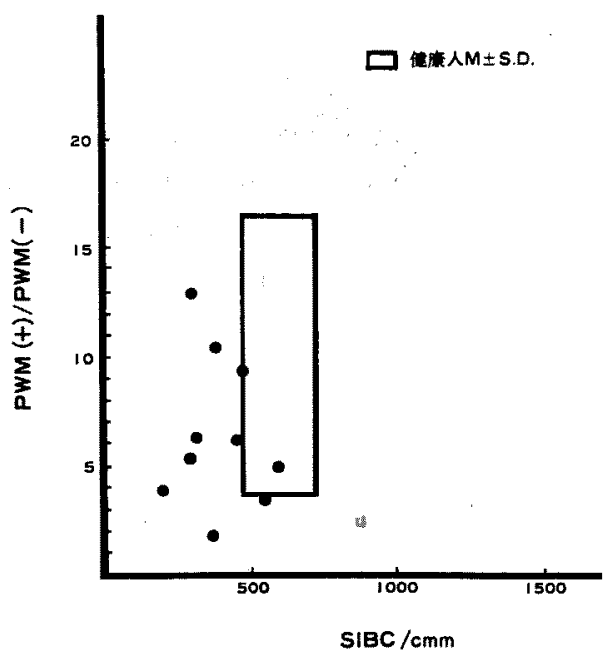

図 5，再生不良性貧血患者末梢血 リンパ球（S I B C）と PWM反㤝性の相関
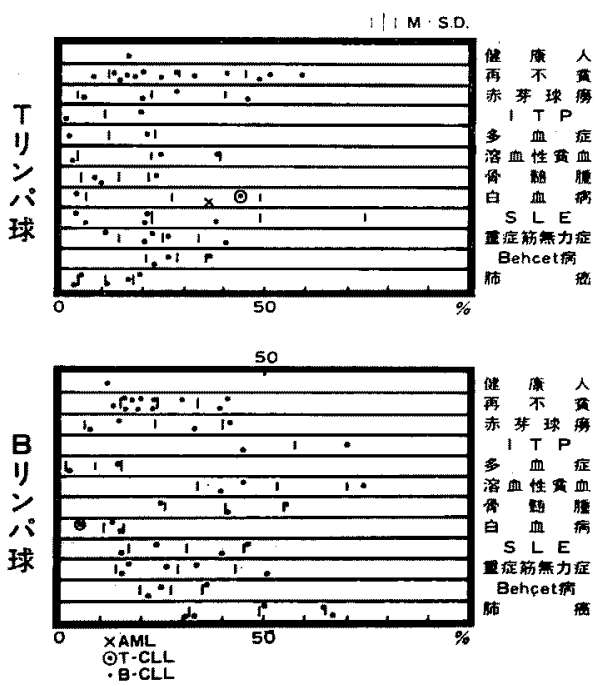

図6、骨髄リンバ球

結局，再生不良性貧血のリンパ球は重症になる ほど実数が減少し，T-cell, B-cellもともに減少 し, surface markerの異常が著しくなり，PHA 反応性も低下し，それは䯚䯣内での免疫反応に基 つくと，同時に，骨䯣内リンパ球産生の低下を反 映するものと考えられる。

d）再生不良性貧血患者骨髄のリンパ球の subpopulation
再生不良性貧血の骨髄に括けるT-cell抢よびBcellの陽性率はT-cell $28.5 \%$ と高值を示す。これ を他疾患と比較してみると（図6），IＴＰでは T-cellが減少し，B-cellが増加して㧊り，溶血性 貧血，骨䯣腫でもB-cellが増加するるから， target organでのB-cellの役割が示唆されているるのと考 えられる。

e）再生不良性貧血患者の胸腺 ${ }^{14)}$

Pneumomediastinography ${ }^{15)}$ Kより再生不良性貧 血患者の胸腺陰影を測定すると，少数例ではある が平均 $11.9 \mathrm{~cm}^{2}$ で，この大ささは橋本甲状腺炎， Behçet病, Sjögren症候群, 重症筋無力症のそれ にほぽ敵し，陰影は濃淡のむらがあつてcystic な感じがあり，胸腺遺残組織への脂肪の混在を示 唆する。

実験生物学的に，胸腺がリンパ球のhomeostasis に主役を演じていることは事実で，かかる胸腺陰 影の执大は再生不良性盆血においては，胸腺から の骨骾造血抑制物質の産生があるのではないかと いら考皇 ${ }^{16)}$ 支持する結果とも考えられる。

いずれにしても，再生不良性貧血の成因にかん して、リンパ球ならびに胸腺の演ずる役割につい てはさらに詳細な研究が必要である。

f）薬物に上る続発性再生不良性顀血につい $\tau$

小宮 ${ }^{17}$ による全国集計報告でも，続発性再生不 良性贫血の原因として，いくつかの薬剤があげら れており，市丸ら ${ }^{18)}$ は薬物過敏症の薬物によるり ンパ球幼弱化現象の結果から，薬物が生体内で時 飞抗原として働き，骨䯣造血障害，血球障害を惹 起すると推定しているが，この薬剤過敏反応を実 証する方法の開発は，本態性再生不良性貧血の成 因解明のためにる甚だ重要である。

その一方法として ${ }^{75}$ Se-selenomethioninによるり ンパ球の抗体産生能の測定法 ${ }^{19)}$ を, sulfonamideに よる再生不良性貧血に応用 乙てsulfonamideの過 敏性を証明した ${ }^{20)}$ 。

症例は49才の主婦で肺結核として I NHおよび sulfa dimethoxin(sulxin) $0.5 \mathrm{~g}$ /日の投与を受け 


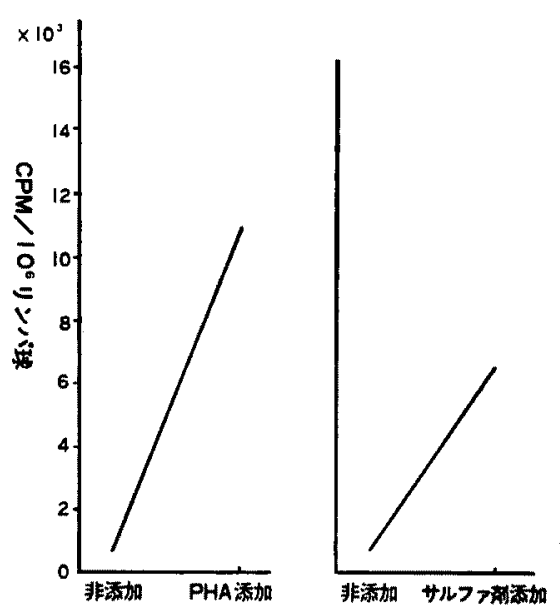

因 7。PHA添加時括よびサルフ 剂添加時に 地けるglobulin合成（藤○登例）

ていたところ貧血を来たし，骨髄像では赤血球系 $0 \%$ erythroid aplasiaの像を示し，PMGの胸 腺像の払大がみられたが，薬郕を中止して約 1 力 月で貧血は回復した。

この患者のリンパ球を ${ }^{75} \mathrm{Se}$-selenomethionineを 加えた培責液で 4 日間培養し， $\gamma$-グロブリンに取 り込まれる75eを測定して，リンパ球の抗体産生 能を調べると，P H A 添加によるstimulation index は14.6と高值を示し, sulxin添加によつてる index 8.9となり， sulxinに対する過敏反心のあること が認められた（図7）。

\section{v. 再生不良性筫血の病型}

本症の骨髄機能障害の程度は様々で, 病理所見

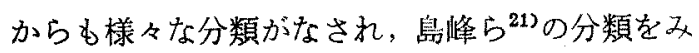
ても無形成型から過形成形まで様々である。

われわれの教室では, 臨床骨髄組織培盖による 所見と，骨骮像を組み合せて，I型：骨髄内血 球抑留型, I 型: 成熟抑制型, 四型: 生成障 害型, IV型： 混合型, V型：沉骨䯣揬型の 5 型に分類している防が，臨床経過，予後などを占 らためにも甚だ有用である。

\section{VI. 再生不良性賓血の病態}

病態の把握は本症診断の補助的方法として甚た 有用である。

\section{1) Sideroblastogram ${ }^{28)}$}

本症 ではsideroblast各型の出現率が特徽的な patternを示し，診断の一助となる。

2) 血清鉄值㧊よびunsaturated iron binding capacity（不飽和鉄結合能）（U I B C）

前者の上昇と, 後者の低下も本症に特徽的であ る。

3) Ferrokinetics

本症では ${ }^{59} \mathrm{Fe}$ の肝・脾への集積が認められ，骨 髄への集積は甚だ少なく，血柡鉄消失時間 P I D $1 / 2 \mathrm{~T}$ は延長し，赤血球鉄利用率\% R C Uは低下 $L$, red blood cell iron turnover (赤血球鉄交代 率）（RIT）为低下して特徽的なpatternを示 す。

4）亦血球寿命

大部分の症例で短緶がみられる。

5） ${ }^{51} \mathrm{Cr}$ 標識障害赤血球による脾clearance

正常に比し，延長寸るものが多く，脾に和ける sequestrationの低下がうかがわれる。

6）骨髅シンチグラム

99mTc-sulfur colloidによるシンチグラムでは， 再生不良性貧血はほとえどactive bone marrowの 描出がみられないるのから，躯幹骨たけけに限局縮 小したもの，さらに不鮮明ながらもびまん性に拡 がりをもつもの，骨幹部に浱浽入り交つた島嶼状 陰影を示するのなどさまざすであるが，いずれ も，それ侯れの症例のactiveな造血巣の分布にほ ぼ一致して括り，造血能低下の状態を示寸。

7）再生不良性貧血の脂肪酸代謝 ${ }^{26)}$

${ }^{14} \mathrm{C}$-acetateの骨髓細胞への取り込多をin vitro でみると, 本症ではミリスチン酸, パルミチン酸 の合成が著しく，炭素数20以上のものの合成は著 明に低下する。これは骨髄造血能と密接な関係が あるるのと考えられる。

8）再生不良性貧血のアミ，酸代謝 27)

本症では血清遊離アミノ酸は概して少なく，尿 中へのアミ，酸排出が多い傾向があり，未知物質 の出現もみられる.

vII. 再生不良性賓血と他疾患との関係 
1) 白血病との関係 28

教室の実験白血病研究によれ《゙, 20-methyl cholanthrene染布 ${ }^{29)}$ あいはRauscher virus接種によ $る^{807}$ 白血病発生実験でも前白血病期沉沉血球減少 が認められる。ヒトでも非定型的再生不良性貧血 と非定型的白血病の鑑別には困難なことが多く, 非定型的再生不良性貧血の病態の解析には，とく に入念である必要がある。

\section{2) P N}

再生不良性貧血との関連で，発作性夜間血色素 尿症paroxysmal nocturnal hemoglobinuria (PNH) は重要である。

長谷川 ${ }^{81)}$ は P N Hを再生不良性筫血の型で発症 した P N H， P N Hの経過中に再生不良性貧血の 型を示寸症例, aplastic anemia-PNH-syndrome症 例の 3 型に分けているが，それぞれの関連は今後 追究されるべき重要な問題の一つである。

3）肝炎之の関係 ${ }^{82)}$

肝炎経過中に再生不良性貧血の発生がみられる こと, chloramphenicol投与により萑起される肝炎 一再生不良性貧血症候群などの報告も相次いでお りとくにvirusとの関連で興味深い問題である。

\section{VII. 再生不良性實血の治療}

副腎皮質ホルモン製剤が再生不良性資血の治療 剂として導入される以前，すなわち昭和28年以前 の本症の死亡率は85\%に招よんでいた ${ }^{88284}$ が，副 腎皮質ホルモン剂の出現以来33〜45\%に低下し，

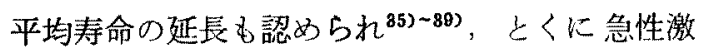
症型に対する本凧の効果は著しい。

さらに近年にいたり，蛋白同化ステロイドホル モン剤が，より強い延命効果をあげるといら報告 がなされている40)41).

梅原 ${ }^{42)}$ は副腎皮質ホルモン剂の効果はsinocapiI laropathyのsinocapillayの修復, 浸出液の除去によ るsinocapillary-haemocytoblast blockageの排除か; 重要な作用であり，蛋白同化ホルモンの効果は $\mathrm{R}$ $\mathrm{ES}$ 機能克進, 細網細胞书よび毛細管新生作用に より, hematopoietic inductive microenvironment (HIM) の改善, transport機能の促進, 洞・毛綀
管新生作用による造血機能の再生作用であると しているが， stem cell systemつ夷験からはstem cell系ではerythropoietin responsive cellのerythropoietin 対する反応性の改善に作用する如き成 績 ${ }^{(3)}$ む得られており，かなりの効果が期待出来る ようである。

1）副腎皮質ホルモン剂の効果

われわれは副腎皮質ホルモン剤とAＣＴＨの併 用療法を本症の基本治療法として扰り，その効果 については後述するが，かなりの効果のあること は既に確認されているところである。

2）蛋白同化ホルモン剤の効果

長谷川 ${ }^{44)}$ の集計に上れば，蛋白同化ホルモン剤 により本症を寛解するに至るまでには，かなり大 量の投与量が必要である。

男性ホルモン投与では大量投与の方が有効率が 高く，蛋白同化ホルモン剂投与では有効率は投与

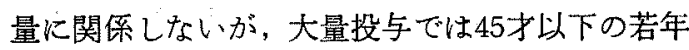
群に，少量投与は高年者で良好な成績を示してい る。

性別による有效率は女性の方に高く，投与期間 では 6 カ月以内では若年者が良く，高年者では 6 カ月以上の持続投与がよい結果を得ている。

しかし副作用として肝障害, 糖疗病, 男性化作 用などがあり，それらが出現すれば投与中止，あ るいは減量を行なつて，充分なる钼察を行ならこ とが必要である。

3）摘脾療法について

河北 ${ }^{45)}$ は多数の本症に摘脾を行ない，高い有効 率をあげて打り，長いものは38年にも及んで生存 している。

われわれの教室でも10数例の症例に摘脾を行な つているが, 摘脾群は平均寿命も, 摘脾後の生存 期間も，非摘脾群に比しやや長い上うである。こ れらの総体的な印象快次の如くである。

a) 摘脾後 5 年むでの死亡者が圧倒的である。

b） 45才以下の若年者によりよい効果が期待で きる。

c）摘脾までの治療期間は 1 年以上あることが 
望ましい。

d）性別にはあまり関倸がない。

e）摘脾後のリンパ球のsubpopulationおよびそ の機能： 摘脾後リン八球数，T-cell $\%, \mathrm{~B}-$ cell $\%$

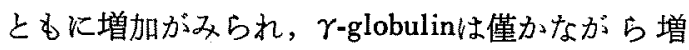
加するが，P H A 扣よび P WM反応性は低下する.

以上より 1 年以上にわたつて治療を行ない，ど んな治療にも反応しないような症例に対しては， 摘脾は良い療法ではないかと考皇られるが，その 適応については慎重でなければならない。

われわれは摘脾の適応を考兄る場合に，次の如 きことを参考としている。

a ）他の治療に反応しないこと，b) ${ }^{51} \mathrm{Cr}$ 梆識 障害赤血球による脾clearanceの比較的短縮，c） ${ }^{51} \mathrm{Cr}$ よる赤血球寿命 $の$ 短縮， d) ${ }^{99 \mathrm{~m}} \mathrm{Tc}$ sulfur colloidによる骨髄スキャンで骨髄分布がほとんど 認められない。

\section{IX. 教室における本態性再生不良性實血の治 療と予後の解説 ${ }^{46)}$}

昭和 28 年より昭和 46 年 9 月迄の間に教室に入院 した本態性再生不良性貧血患者 122例（男74例， 女48例）について46年 9 月現在で調查した結果を 示すと次の如くである。

1）性別ならびに発生年令別生存率

40才以上の老年者群では生存率が低く, 予後が 悪い。

男性生存率は $40.7 \%$ ，女性生存率は $54.2 \%$ ， 平均 $45.9 \%$ で, 全症例の平均生存期間は 54.6 力月

( 4 年 6 力月), $50 \%$ 生存期間は 27 月 月 $(2$ 年 3 力 月）である。

2) 生存率曲線

推定発病時からの生存期間と，診断確定時から の生存期間はほぼ平行して推移し，診断確定時よ りの 1 年生存率は $59.3 \%, 3$ 年生存率は $46.3 \%, 5$ 年生存率 $38.2 \%, 10$ 年生存率 $15.4 \%$ と減衰与る。

3）生存期間による死亡率

全症例を生存期間の長い順に配列してみると， 1 年も生存できず早期に死亡する者が圧倒的に多 く，3年以上発病後生存した場合には次第に死亡
者が減少する．30カ月から50カ月以上経過すると 死亡率は13〜16\%となり，90カ月以上では3.3〜 $3.8 \%$ の死亡率となる.

4) 病型別生存曲線

I 型が压倒的に良好で，50\%生存期間も77カ月 （6 年 5 力月）と最長を示す. 平均生存期間でも I 型 113土63.9力月（ 9 年 5 力月）と最も長く, V型が $7 \pm 8.5$ 力と最も短かく、病型より活ぼ 予後を占らことができる。

薬剂に対する反応も I 型が最も良く，V型が最 も悪い，II，III，IV型の中間型は I 型和よびV型 の中間的反応をみせるが，むしろV型に近い。

5）治潦別転帰

副䶤皮質ホルモン剂とA C T H併用群の生存率 は53.9\%と高率を示し，50\%生存期間も3 年とは るかに延長して，最も効果があると考えられる。

6）摘脾療法について

摘脾例全体の生存率は $47.0 \%, 50 \%$ 生存期間は 55力月（4年7 月月）であるが，副腎皮質ホルモ ン剤とA C T Hを併用した群にのみ生存例がみら れる。

7）治潦別生存曲線

$50 \%$ 生存期間は摘脾 55 力月 ( 4 年 7 力月), 副腎 皮質ホルモン, A C T H併用群36力月 ( 3 年), そ の他20力月( 1 年 8 力), 副腎皮質ホルモン単独 使用群10カ月である.

8）経時的治療別生存率

1 年目の生存率は摘脾群が最も良く，次いで副 腎皮質ホルモン，A C T H 併用群が良好で，2 年 目になると他の群との差が一層歴然としてくる，

9）入院時血液像と予後との関係

赤血球数 160 万以下， $\mathrm{Hb} 35 \%$ 以下，網赤血球 数 1 万以下ならびに骨髄赤芽球百分率 $20 \%$ 以下は 予後不良の兆候といえるようである。

10）短期 (10力月未満) 死亡者と長期（90力月 以上）生存者の比較

診断時の検查成績の比較から $\mathrm{Hb} 35 \%$ 以下，骨 䯣有核細胞数 6.5 万以下，骨䯣赤芽球百分率 $18 \%$ 以下，血清調 $150 \gamma / \mathrm{dl}$ 以上が短期死亡者の一つの 目安となるようである。 


\section{0. おわりに}

本症にかんしては成因の解明, 根治療法の開発 等, 重要な問題が山積しているのが現状である. 今後の飛躍的な進歩を希望しながら本稿を終え る。

本文中に紹介しだわれわれの研究の一部は厚生省特 定疾患調査研究補助金に上るものである。

\section{文献}

1) 高久史麿：再生不良性筫血の䛦断基染に関乙 $\tau$, 厚生省特定次患再生不良性賃血の成因々治療, 予防に関寸る研究，昭和48年度業精集，再生不良性 資血（以下厚生省再生不良性督血之略），II：205， 1974。－－2）青木国雄，大谷元彦：再生不良性貧血 の全国実態調查，厚生省再生不良性筫血，II : 9 , 1974. 一3) 栗原 登: 死亡珫計からみた再生不良 性貣血の疫学的研究, 厚生省再生不良性筫血, I : 15，1973，一）－高久史厤他：再生不良性筫血飞打 ける造血幹細胞の動態, 厚生省再生不良性資血, I :

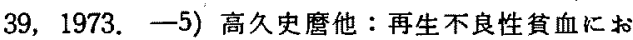
ける造血幹辎胞の動態，厚生省再生不良性算血，II： 93，1974. 一6）高久史黁：再生不良性筫血の成因 一造血幹細胞一, 最新医学, $29: 1024,1974 .-7)$ Jandl, J.H.: A symposium on the mechanisms of disorders of erythropoiesis. Introduction Medicine, 43: 615，1964. 一8) 梅原千治：再生不良性 哲血の成因一 HIM, Microcirculation disorders, Sinocapillaropathy の立場か ら一, 最新医学, 29: 1031, 1974. -9) Knospe, W.H. and Crosby, W. H.: Aplastic anemia: A disorder of the bonemarrow sinusoidal microcirculation rather than stem cell failure. Lancet, i: 20, 1971. -10) 岩 埼一郎他：重症笳無力症㧍上び胸腺腫を併発した

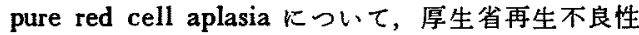
筫血, II : 129, 1974. - -11) Andersen, S.B. and Ladefoged, J.: Pure red cell anemia and thymoma. Acta Haemat., 30: 319, 1963. -12) Björklund, B. and Hellstrom, L.: Studies on the effect of anti-bone-marrow serum. Acta Med. scand., 139: 122, 1951. -13) Lay, W.H. et al.: Binding of sheep red blood cells to a large population of human lymphocytes.Nature, 230:531, 1971. - -14）岩崎一郎他：再生不良性筫血々胸腺 機能, 厚生省再生不良性筫血, II : 121，1974。 15) 三辺 謙他：内科領域における Pneumomediastinography の重要性, ことに胸腺異常診断一の 利用について，最新医学，20:1673，1965. -16) Hirst, E. and Williams, H.B.L.: Intrathoratic lymphoid hamartoma. Thorax, 19: 469, 1964. 17) 小宮正文, 岡村裕喜: 「臨床病態」調查票の整 理報告 I，厚生省再生不良性筫血，II : 177，1974. 一18）市丸道人，木下耕一郎：菜物誘発の再生不良 性貨血，厚生省再生不良性算血，II : $243 ， 1974$.

昭和50年5月10日
-19) 長谷川真他： ${ }^{75}$ Se-selenomethionine を用い たりンバ球の globulin 合成能, (in vitro) 臨床血 液, $13: 787,1972$, - -20) 長谷川真他 : 胸腺肥大 を合垪したサルファ昘による再生不良性筫血の 1 例（会）, 第16回日本臨床血液学会, 講演抄録集: 75，1974，－21）島峰徽郎他：再生不良性筫血骨 瞇の病理学的分類の桧討, 厚生省再生不良性貧血, II : 145，1974。一22) 平木 絜, 高橋 功：再生 不良性貟血の臨床, 臨床と研究, 49 ：109, 1972. -23) 木村郁郎他：骨骮造赤血球機能判定法々し 七の sideroblast 检索，日本血液学会雑誌，21:727, 1958. -24) Iwasaki, I.: Distribution of active hematopoietic bone marrow (bone marrow scintigram). Acta Haemat. Japonica, 36: 661, 1973. 一25) 吉岡溥夫他： ${ }^{99}$ 以c- 硫黄コロイドによる骨

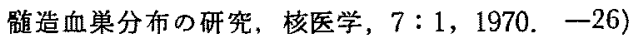
木畑正：稩胞に叔ける脂質代謝一特に血球につ いて, 診療, $23: 2045,1970 .-27)$ 岩崎一郎, 原 昭則：再生不良性省血のアミ，酸代謝，厚生省再生 不良性荋血，I：139，1973，一28）岩畸一郎，高 橋 功：非定型的再生不良性貧血について，厚生省 再生不良性貧血，I：173，1973，一29）平木 潔 他：発癌性化学物犋に上る白血病の発生について, 綜合臨床, $12: 1757 ， 1963 ，-30)$ 入野昭三 : Rauscher ウイルスによるRauscher 病 (赤白血病) の発生機序に関する研究，日本血液学会雑誌，28： $877 ， 1965$ ，一-31）長谷川弥人，高橋隆一：再生不 良性䝷血亡 P N L 一関連, 厚生省再生不良性䝷 血, II : 227,1974 , - 32) 長谷川弥人他：肝炎後

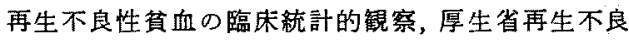
性䆩血，II : 219，1974。－33) 長谷川弥人：本邦 における再生不良性䆩血の現況，日本臨床，24： 1501，1966。－－34）伊藤久雄：再生不良性貧血の 臨床追加発言，臨床血液，7:225，1966。-35) 柏 原千治他：再生不良性貧血一その成因，治療，社会 復㴆, 臨床科学, 4:542,1968. - -36) Adams, E. B.: Aplastic anemia, Review of twenty seven cases. Lancet, i: 657, 1951. - 37) Israels, M. C.G. and Wilkinson, J.F.: Idiopathic aplastic anemia. Incidence and management. Lancet, i: 63, 1961. -38) Mohler, D.N. and Leavell, B.S.: Aplastic anemia: An analysis of 50 cases. Ann. intern. Med., 49: 326, 1958. -39) Smith, L. W.: Report of an unusual case of aplastic anemia. Amer. J. Dis. Child., 17: 174, 1919. -40) 三輪史朗他：Oxymetholone 大量投与による再生 不良性䆩血の治㙩，厚生省再生不良性貧血，I： 189, 1973. 41) Sanchez-Medal, L. et al.: Anabolic androgene steroids in the treatment of aequired aplastic anemia. Blood, 34: 283,1969. 42）梅原千治他：再生不良性貧血の治療に関する 研究, 蛋白同化ステロイド療法を中心に，厚生省再 生不良性督血, II : 341，1974，一43) 前川正他： 
再生不良性筫血の病態並びに治療に関す当研究，特 にそのER Cの变動と蛋白同化水ルモン剂の作用 嘰序について，厚生省再生不良性貧血，II : 325 , 1974. 一45) 長谷川弥人他：再生不良性損血の治潦 法の研究，厚生省再生不良性省血，II : 317，1974.
一45）片山則孝他：再生不良性盆血にお。る摘脾 療法の効果, 曆生省再生不良性筫血, II : 367, 1974.

-46）岩渏一毁，有森茂：本態性再生不良性貧血 122症例の治療亡予後の解析, 厚生省再生不良性真 Ifll, I : 181, 1973.

\section{（1） 再生不良性貧血の臨床 討論要旨}

\section{啠問京大第二内科 恒松德五郎}

再生不良性貧血の成因に自己免疫的機序が閣与 するかどらかは非常にattractiveなテーマと考党 ます，先生がりンパ球subpopulationの測定もかか る意味でのフプローチかと察します。リンパ球 subpopulation異常を認めていられるようです が、これらは原因と結びつくのか或は結果的なる のでしょらか。

\section{質問自治医大内科 高久史麿}

赤芽球勞の患者では最近赤芽球に対する抗体と エリトロポエチンに対する抗体の 2 種類がみつか つております。先生の症例では抗体は赤芽球に対 してのみ証明されたのでしようか。

質問 国立がんヒンター病院 木村禧代二

1）再不貧患者に括ける脾の関与にかんし，何 か、特別な根拠となる様な所見は認められないか。

2）再不貟における溶血の関与如何.

\section{質問 徳島大第一内科 三好和夫}

再生不良性筫血の骨䯣のhyperplasticの型をaplasticの型と同じ疾患と机考克ですか, hyperplastic の型の予後と治療の特殊的なことはありません か.

啠問国立名古屋病院 日比野 進

ステロイドホルモンの効果についてとら考える か.

摘脾のindicationは。

\section{答岡大第二内科 岩崎一郎}

（恒松先生に）再不貧に拈けるリンパ球sub_ populationの変化は，再不貧の病因なのか，結果 なのかどちらとる現段階ではいえない，しかし今 までのdataからは生体のhomeostasisによる変化で あつて結果ではなかららかといら考吝が強い。胸
腺陰影の拡大も同様のことがいえるのではないか と考支る。

（高久先生に）方机わのP R C A症例では 赤芽球抗体にはつきり検出されたが，他系統の血 球に対する抗体は検出しなかつた。

（木村先生に）脾缄と骨髄の，ことに綝内系 機能はantagonisticであるといら結果を動物実娩 では得ており，再不貧の骨䯣scanでも摘脾前にほ とんどactive bone marrowがみられないものが摘 脾後びまん性 $\operatorname{scan}$ 像として現れる症例もあり，再 不貧に打ける脾蔵の影響は大きいと考える。溶血 も重大な影響をもら，再不貧の赤血球寿命は短縮 傾向漒い。

教室分類病型 Iすなわ占hyperplastic typeは他 型にくらべて予後が断然よい.

しかし，それでも $1 / 8$ の症例は激症型となつて死 亡するし，病型は流動的であつて，I 型から他の 型へ変ることもよくあるので，I型も他の型も同 一疾患と考疮劣。

（日比野先生に）1）ステロイドホルモンり 効果は，止血と消炎にあると思らが，A C T Hの 併用はこれら作用を増強し，ステロイドの使用量 の軽減む可能となるので教室では両者の併用療法 を基本的治療方法として行なつている。

2）摘脾のindicationは赤血球をlifespan, splenic clearancé,骨髄ンンチグラムなどを参考にし ているが，今後摘脾前後におけるこれらの検查成 續を集積して，さらに確実なindicationを確立す る必要がある。

3）Lifespan対する輸血の影響は，はつきり しない。 